\title{
EUROPEAN INTEGRATION, VALUATION, AND EXCHANGE: TOWARD A VALUE THEORETIC UNDERSTANDING OF TRANSNATIONAL SOCIALITY IN THE EUROPEAN UNION
}

\begin{abstract}
The article elaborates on a possible framework to conceptualize the notion of 'value' with a view to European integration. In the political rhetoric of the European Union, 'integration' usually refers to both the widening of policy fields and societal sectors for supranational governance and to an increase in the depth of regulation. 'Value', in its turn, usually comes in the plural, denoting certain principles often held to be part and parcel of Europe's cultural heritage and the European Union's political project. In contrast to these discourses, this article suggests exploring integration with a view toward transnational social relationships in the EU and to conceptualize value as a term that refers not to principles or beliefs, but to acts of valuation as embedded in those transnational relationships. The sociology of the EU, although having produced a plethora of studies on various forms of transnationalism in Europe, has not developed a particular conceptual interest in the notion of exchange as of yet. The article addresses this lacuna through a conceptual discussion of anthropological work that interconnects questions of social valuation with an analysis of exchange practices. It arrives at an understanding of valuation as emanating from a particular understanding of exchange which arises out of the logic of the 'gift'. This conceptualization is then applied to one of the most prominent, long-lived, and widespread practices of exchange in the EU, namely, town twinning. Referring to a qualitative research project conducted
\end{abstract}

* Prof. Dr., Department of Sociology; e-mail: Andreas.Langenohl@sowi.uni-giessen.de 
by the author, it is demonstrated how particular understandings of twinningrelated exchange trigger valuations of transnational European relationships, and which factors possibly counteract such valuations. The article concludes on more general implications of the approach suggested here.

Keywords: European Union, European integration, value, exchange, sociality, sociation, town twinning

\section{INTRODUCTION}

This article elaborates on a possible framework to conceptualize the notion of 'value' within the framework of European integration. These very notions, value and integration, can be found at the core of contemporary political rhetoric in the European Union (EU). While 'integration' usually refers to both the widening of policy fields and societal sectors for supranational governance and to an increase in the depth of regulation, 'value' usually comes in the plural, denoting certain principles often held to be part and parcel of Europe's cultural heritage and the European Union's political project. In contrast to these discourses, this article suggests exploring integration with a view toward transnational social relationships in the EU - which have become the object of investigation for what is called the sociology of the European Union - and to conceptualize value as a term that refers not to allegedly-given principles or beliefs, but to acts of valuation as embedded in those transnational relationships.

Thereby, the article both empirically and conceptually focuses on practices of exchange as sites where European integration takes place (or does not) and where social relationships are valued (or are not). Historically, and on the institutional level, European integration has often been connected with an expansion of practices of exchange. European integration can thus be understood as a political project with a sociological imagination that puts the broadening and deepening of 'sociation' (Vergesellschaftung, Georg Simmel) at center stage. In this political project, exchange has played a particular role, as it was through exchange that postwar European integration was meant to be kick-started via economic exchange, cultural exchange, quasi-diplomatic exchange, educational exchange, etc. Thereby, different forms, modalities, and understandings of value were implied, ranging from economic value (epitomized in the Single Market) to cultural valuation (as in the various cultural exchange projects orchestrated by the EU) to professional appreciation (as in the administrative and professional exchanges to create 'best practices' for various policy fields). Outside the strictly politically- 
institutionalized sphere however, practices of exchange have been addressed with less emphasis. The sociology of the EU, while having produced a plethora of studies on various forms of transnationalism in Europe such as work-related migration, intermarriage, joint corporate property, tourism, or even 'domestic transnationalism' (such as attending to media from other European countries), has not developed a particular conceptual interest in the notion of exchange as of yet (see section 2). The present article will address this lacuna through a conceptual discussion of anthropological work that interconnects questions of social valuation with an analysis of exchange practices. This way, the article will arrive at an understanding of valuation as emanating from a particular understanding of exchange, one which arises out of the logic of the 'gift' (section 3).

Additionally, the sociology of the EU has thus far not paid much attention to one of the most prominent, long-lived, and widespread practices of exchange in the EU, namely, town twinning. This lack of interest is striking, given that the European Commission itself holds town twinning to be one of the most important factors in the raising of a European consciousness for citizens. Furthermore, it was among the first transnational initiatives after the end of the Second World War, in practice in its present form for 70 years now, and ultimately leading to more than 40,000 twinning relationships between towns and cities across Europe. Referring to a qualitative research project conducted by the author, it is demonstrated how particular understandings of twinning-related exchange trigger valuations of transnational European relationships, and which factors possibly counteract such valuations (section 4). Lastly, as town twinning is important for understanding European integration not only as an empirical example but also from a conceptual perspective, the article concludes on more general implications of the approach suggested here (section 5).

\section{THE SOCIOLOGY OF THE EUROPEAN UNION: EXPLORING SOCIAL TRANSNATIONALISMS}

The sociology of the European Union has developed out of a bid to analytically rescue the genuine social logics of European integration from a political science view that focuses mostly on institutional logics of governance such as intergovernmentalism and supranationalism. In this bid, forms of 'social transnationalism' [Mau 2010] within the EU have received particular attention, as an analysis of their varieties and intensities allows for an evaluation of the political aims and mechanisms of European integration and the effects of related European policies [Favell/Guiraudon 2011; Favell/Recchi 2011]. Thereby, the literature has come 
with an impressive range of different empirical forms of social transnationalism. This regards, for instance, migration related to gainful employment in other European countries [Favell 2008; Favell/Recchi 2011]; visits to EU countries and sociability with EU foreigners [Mau/Mewes 2012]; the degree and intensity of 'strong' social ties such as marriages, joint property, and transnational civil society mobilization [Díez Medrano 2011; Van Mol et al. 2015]; and the reception of European mass media and so-called 'domestic transnationalism', i.e. cognitive and evaluative everyday orientations within a European reference frame [Fernández et al. 2016]. The spectrum of social transnationalism subjected to investigation thus ranges from biographically important processes, like migration to another EU country, to forms of a more or less durable formation of social relationships, to continual information regarding processes within the European Union.

Departing from earlier approaches in the sociology of the EU which had emphasized the structuring power of EU institutions in their analysis of processes of European integration [see also Bach 2015], current studies share the consideration that institutional processes in Europe initiated by the EU institutions - for instance, the single market, the Schengen agreement, free movement of labor, etc. - enter into interdependencies with transnational social processes on a European level, yet that the respective logics of both aspects of Europeanization cannot be reduced to one another. An apt example for this argumentation can be found in the works by Adrian Favell and others [Favell 2008; Favell/Recchi 2011], in which the authors address the ambivalent consequences of the introduction of the free movement of labor within the EU: On the one hand, the free movement of labor tends to privilege individuals with high formal qualification, which contradicts with the diffusion of a Europeanized understanding of work throughout all societal strata. On the other hand however, it has created a legal framework for young professionals, mostly those working in the upper service sector and expressing dissatisfaction with the normative structures of their respective national environments, to pursue new ways of life in the absence of severe legal and social risks. According to Favell, the sociocultural significance of this interdependency between institutional frameworks and social strategies should not be underestimated, even given the comparatively small number of individuals and households who embark on this strategy.

To sum up, the sociology of the EU has thus far capitalized on fleshing out the ways in which changing European political and legal norms have been addressed and appropriated by people in Europe that engage in transnational frames of reference. Here, the sociology of the EU has treated social processes that respond to the valorization of exchange and circulation by the EU: tourism and migration 
patterns and motives responding to the EU norm of free movement of labor and to the Schengen Agreement, student mobility responding to the Bologna Process in the system of higher education, or patterns of transnational private or corporate ownerships responding to the respective EU legislation. Additionally, it has had quite a lot to say about what Europeans value in these exchange practices: the pursuit of transnational lifestyles, upward social mobility aspirations, or simply a better life for themselves and their loved ones. Still however I am not aware of any work done with respect to understanding these practices of exchange and valuation in a broader conceptual manner as practices of exchange and valuation. Why is this so? And why is it important?

The sociology of the EU has so far mostly been reacting to institutional frameworks, exploring how these are filled, appropriated, and renegotiated in transnational social relationships. It has been responding to a political understanding of EU integration, but to date has been rather hesitant in coming up with deeply conceptualized notions that would capture basic patterns and tendencies of EU sociality. The only attempts in this direction that I am aware of have been attempts to develop basic concepts in sociological theory, such as Simmel's notion of 'sociation' or the notion of 'conflict', into a conceptual framework for a sociology of Europe. 'Sociation' has been used to emphasize the normatively neutral character of processes of European interdependencies, while 'conflict' has been invoked in a similar manner to de-normativize the debate about European integration [Krossa 2009, 2011; Vobruba 2008, 2012]. Furthermore, attempts to analyze European integration from the viewpoint of outright normative political notions such as 'European cosmopolitanism', start out with a political-normative agenda partly taken from EU discourse and mainly elaborating on the ramifications of the EU's character as a political project [Beck/Delanty 2006]. So, while the larger part of the sociology of the EU has tended to empirically trace the effects of EU policies in transnational social relationships, social-theoretical endeavors have either tried to sociologize understandings of European integration "on nonnormative grounds" [Krossa 2009] or, conversely, have seen Europe and the EU as a testing ground for grand social philosophical concepts such as 'cosmopolitanism'.

Against this backdrop, I suggest a further perspective on the relationship between social studies of the EU and their referent object, the EU itself. This approach would first reconstruct, from a social theoretical perspective, the complex meaning of vernacular notions used in integration discourse and operative in integration practice, such as 'exchange' or 'value'. To this end it would defamiliarize the political meaning of these notions by social-theoretically grounding them. Second, these reconstructed notions of 'exchange' and 'value' 
can then be used as a heuristic for interpreting empirical material. 'Exchange' and 'value' are indeed good candidates for such an endeavor, not only because they lend themselves well to developing complex yet concise understandings of social interrelations (as will be shown in the next section), but also because they intrinsically belong to the character of the EU as a political project and are constantly being invoked both in discourse and practice. The suggestion of this paper is thus to look at social transnationalism from the perspective of rigorously, social-theoretically conceptualized notions of exchange and value which are able to both respond to the integration idiom of the $\mathrm{EU}$ and its political valorizations and at the same time insist on the necessity to dis- and re-locate them.

My testing ground for this approach is a widespread practice without particular currency in the sociology of the EU thus far: town twinning. Usually, town twinning figures into research as a subcase of broader societal and political processes and tendencies, for instance, in the context of studies on urban transnationalism, bottom-up processes of Europeanization, or new modes of transnational governance [Leitner 2004; Grosspietsch 2009; Clarke 2009; Jayne et al. 2011; de Villiers et al. 2007; Joenniemi/Jańczak 2017]. The still-rare available studies that focus on the logics of town twinning itself in turn foreground the heterogeneity of the practice field of town twinning [Lottermann 2009, 2010, 2016; Langenohl 2014, 2015]. Nick Clarke [2011] has suggested to approach this heterogeneity from the analytical perspectives of 'device', 'repertoire', and 'form':

as a device (for producing topological proximity between topographically distant localities); a repertoire (of formal agreements, trade delegations, joint projects, exchange visits etc. but that also forms one device in the higher-order repertoires of peace activists, council officers, business leaders, civil servants etc.); and a model (in that town twinning as a device or repertoire has proved itself to be highly mobile and has been taken up and used by numerous different interest groups, in numerous different contexts, with numerous different ends in mind). [Clarke 2011: 117]

The present article is based on this research insomuch as it views town twinning as a practice field to be analyzed in its own right and on its own terms, while at the same time viewing this field, and its heterogeneity, from the angle of the social-theoretically conceptualized notions of exchange and value, to which I will turn now.

\section{THE SOCIAL CONDITION OF VALUE AND EXCHANGE}

At this point, let me turn to anthropological debates about value and exchange. Cultural anthropology has invested a great amount of dedication into conceptualizing both 'value' and 'exchange' since its disciplinary beginnings, not least 
motivated by a bid to wrest away the concepts of value and exchange from a narrow economic-neoclassical understanding [see Graeber 2001 for a summary of the debate]. The peculiar interest in value found within anthropology has to do with a particularly anthropological understanding of sociality as a force that creates bonds (including boundaries), while at the same time also defining their rules of transformation. A locus classicus for this is Bronisław Malinowski's [1922] report of the 'Kula ring' in Papua New Guinea, which combines a theory of value creation and valuation with a theory of communal cohesion and the maintenance of inter-community relationships through practices of ritual exchange. Reports such as these have been brought together and reassembled in Marcel Mauss's equally-classical Essai sur le don [1954], where the author makes the point that the practice of giving creates value, communality, and social order through the giving away of valuables that then return as communal and inter-communal assets within symbolic orders of valuation. The creation of (symbolic) value through the abandonment of individual assets is one of the most prominent examples for how value emerges as a 'total social fact'. These anthropological approaches move into a conceptualization of value and exchange as fundamental processes in the constitution of sociality, which in turn make them privileged reference points for a fruitful complication of 'value' and 'exchange' that can be found in the European integration vernacular.

This section discusses some important theoretical milestones in the anthropology of value and exchange in three subsections. First, contributions will be discussed that critique the subjectivist notion of 'value', instead making a case that value and valuation are only possible within a normative horizon. There is no a priori distinction, for instance, between 'individualist' and 'collectivist' or 'economic' and 'cultural' values - rather, all values are normative inasmuch as they refer to things that are held worthy of being esteemed [Graeber 2001: 3]. For a sociology of European integration, this has the important implication that all values invoked in such integration processes must be analytically treated on the same level, that is, as normative horizons which are variously and specifically institutionalized while at the same time being subjected to human desires.

Second, values, rather than delineating communities from one another, enable and regulate circulation, traffic, and exchange between them. Studies in the anthropology of value and of gift exchange show that values are invoked regularly not in order to fence off one's own community from any other, but rather function as portals for the channeling of normative expectations between communities. For the sociology of Europe, this line of thought brings along the inspiration to think of value as a vehicle that organizes social processes. 
Third, the recent discussions around the project of turning Mauss's Essai sur le don into a full-fledged social theory will be briefly discussed. These debates are interesting because they perspectivize the question of value in a way that seeks a middle ground between methodological individualism and normativism in social theory. The logic of the gift, and the way the gift is valued, point to a type of social bond that is neither voluntaristic-utilitarian nor collectivistic and socially-coerced, namely, a bond in which normative values in the forms of obligations materialize that still do not force a decision either for or against them.

\section{Anthropological notions of value}

A major resource for the formation of anthropological notions of value has been Marcel Mauss's Essai sur le don [1954], which, according to David Graeber [2001: 151-161], was written in a bid to disentangle the notion of exchange from economic reasoning. According to Mauss, modern economic practices have emerged out of ritualistic practices of exchanging items within and between communities, the rationality of which he does not see in individual utility maximization but in the genuine social logic of fostering, maintaining, and calibrating social relationships. Thereby, the evidence from existing anthropological literature that Mauss assembles in his book does not indicate a uniform pattern for gift exchange. Instead, gift exchange may take the form of a practice that points toward a transcendental reality, like when the norm to reciprocate a gift is grounded on the assumption that the gift is the vessel of a spirit (the Polynesian 'hau') who will return in revenge of the receiver if the gift is neither timely reciprocated nor passed on to the next receiver. Conversely, it may take the form of a social antagonism, such as when during 'potlatch' ceremonies on the American northwest coast, leaders of affluent communities destroyed valuables in a challenge to neighboring leaders until a point is reached when the amount of the destroyed valuables cannot be matched by counter-annihilation, ultimately serving to organize status hierarchies among these communities. The norm to reciprocate that Mauss reconstructs has, according to Graeber [2001: 151-163], often invited interpretations of Mauss as implicitly or explicitly theorizing social cohesion in a tit-for-tat pattern. Against this interpretation, Graeber holds that the logic of the gift is not a transactional logic, but rather highlights the span of time in which the gift is not yet reciprocated and the social obligation to reciprocate it still pending [Graeber 2001: 164-211].

The paradigmatic status of Mauss's gift logic, for Graeber, thus resides in the valuation of certain items as being fundamentally constitutive for social re- 
lationships precisely through being given away and creating an expectation to be returned. Furthermore, this valuation is a fundamentally public affair: it affords not only the givers and receivers as individuals but rather whole communities which assemble in their common valuation of social interdependencies represented by the gift as not-yet-returned [Graeber 2001: 189, 217]. Exchange is thus significant for valuation not as a transaction heading for the settling of accounts and thereby the termination of the social relationship [Graeber 2001:217-228], but instead as an interactional offering which constitutes value at the moment that something valued is given away and reciprocation has not yet taken place, thus creating a dense and somehow tense social relationship awaiting appreciation and permutation through reciprocation.

According to Graeber, the starting point of anthropological reasoning is the argument that values are "ideas about what people ought to want" [Graeber 2001: 3], thus highlighting the fundamentally social and normative constitution of values, irrespective of whether these values are considered as 'economic', 'social', or 'cultural'. Graeber argues that values cannot be reduced to mere conceptions or understandings of what is valuable, but must crucially imply a dimension of meaningfulness [Graeber 2001: 13-20]. In other words, the "ideas" about value imply not only a definition of what counts as desirable, but also carry with them a motivational impulse to actively pursue these values. An anthropological theory of value thus needs "to bring together society and human purposes, to move from meaning to desire" [Graeber 2001:21]. Put differently, such a theory cannot lock the question of how people arrive at their desires into the realm of preferences that need no further theorization (like in neoclassical economics). Conversely, it cannot simply regard values as being socially predetermined. Instead, it requires reconstructing the ways that the object of desire is socially constituted and pursued as meaningful by individuals:

Rather than value being the process of public recognition itself, already suspended in social relations, it is the way people who could do almost everything (including, in the right circumstances, creating entirely new sorts of social relations) assess the importance of what they do, in fact, as they are doing it. This is necessarily a social process; but it is always rooted in generic human capacities. [Graeber 2001: 47]

This brief, and necessarily only partial, discussion of Mauss's and Graeber's reconstruction of the anthropological notion of value demonstrates that value can be redeemed as a concept that combines the element of social normation with the creation of a potentiality to engage with these values. From this perspective, values are a fundamental component of sociality as they articulate rules while at the same time giving incentives to opt for them. I will return to this theorization, 
which has meanwhile been taken up in a broad stream of social theory, in the section Gift exchange as a paradigm of sociality, but before that address in some more detail the question of the role that exchange plays in the materialization of values.

\section{Value, exchange, circulation}

Ever since the publication of Malinowski's Argonauts of the Western Pacific and Mauss's Essai sur le don, anthropological notions of value have been framed and discussed in terms of circulation and exchange of items, persons, and significations. The emphasis of most of the related studies lies not in 'economic' exchange in a narrowly-defined western/northern/modernist sense, but rather in ceremonial and ritualistic practices of exchange. Malinowski [1922], for instance, distinguished between a total of seven modes of exchange and sorted them according to their cultural meaningfulness for the persons and communities involved. The 'Kula ring' that is at the center of his interest - the exchange of necklaces and bracelets on the occasions of reciprocal visits between delegations of island communities, which has a most profound significance for the maintenance of relations among these communities - thereby represents the most socially meaningful form of exchange. Likewise, Mauss focused on highly ritualized forms and modes of exchange that, according to him, are capable of symbolically involving whole communities, and are thus termed 'total social facts'.

The notion that the manifestation of value requires practices of exchange has, since then, come under the scrutiny of differentiation and critique in anthropology [see Graeber 2001: 35-47]. In particular, the identification of exchange and sociality, or social relationships as such, has undergone some criticism. Referring to Annette Weiner's [1992] observation that value may be constituted precisely through exempting objects from exchange, thus defending them as 'inalienable possessions' of an individual or a social group, Jane Fajans has argued that exchange is merely one manifestation among others that materialize social 'circulation' and that such circulation has a profoundly productive, not just exchange-related, significance:

We conceive of production as a process which generates not only products but their values. The values generated in production, however, can only be rendered socially concrete through the integration of the product into the wider society. Circulation is thus the point at which social values are realized. It is critical to distinguish analytically between circulation and exchange, and to recognize that circulation can occur in the absence of exchange. The displays analyzed by Weiner [1992] and Foster (this volume) effect a public recognition and confirmation of values, which thereby accrue to the social identities of the producers of the 
display. Displays here function as tokens of value whose visual images circulate in the public domain without the objects displayed being exchanged. Exchange is, however, an important and common medium of circulation. [Fajans 1993: 7]

The constitution of value in society thus appears fundamentally as the effect of practices of putting objects at the joint attention of a social figuration, be it through production, display, or exchange. From this point of view, it can be argued that exchange refers less to a practice in which objects that are ascribed certain values are being swapped, but rather as a swap which constitutes the values of these objects respectively [Strathern 1993]. In other words, value is the function of the practice of exchange as embedded in a broader array of practices of circulation, not the precondition for exchange. In a similar vein, Nancy Munn [1988] has argued that practices of circulation - not only the exchange of Kula items, for instance, but also the sharing of food and company - have the potential to extend an individual's or a group's sphere of attention and valuation, even beyond the reach of the respective objects proper. For Munn, the concept of 'fame' refers precisely to such an extension: The ritual giving of valued items, such as artful water vehicles, creates a sphere of resonance for a group's reputation even beyond the limits of the exchange network.

We may derive from these discussions the notion that value, in its quality as a 'social fact', emerges from exchange rather than existing prior to it. At the same time, exchange ought to be seen as just one, albeit crucial, modality of 'circulation', understood as the creation of a joint focus of the attention involved in valuation. The strength of these anthropological insights is that they enable us to locate the concepts of value and exchange in a broader array of the logics of sociality: Rather than a clearly delineable practice, value-related exchange seems to condense a certain modality of sociality that has a much broader significance [see Graeber 2001-2019: 227]. This is also the focus of the next subsection, in which I will discuss contemporary rehearsals of Mauss's Essai sur le don as a platform for a new type of social theory.

\section{Gift exchange as a paradigm of sociality}

As in anthropology, social theory has meanwhile reflected on Mauss's notion of gift as having very broad implications for understanding the nature of sociality in general. That is, the logic of the gift has an echo far beyond any narrowly defined practice of gift exchange, while that practice itself still remains at the conceptual and metaphorical center of this new type of social theory. In the context of the Mouvement Anti-utilitariste dans les Sciences Sociales (M.A.U.S.S.), researchers 
refer to Mauss in order to correct what they see as two complementary impasses of social theory. ${ }^{1}$ First, there is the problem that social theory is informed by two competing, and incompatible, major strands of theorizing: On the one hand, the Rational Choice paradigm, a methodological individualism which views social structures and processes as outcomes of individual decision-making based on utility maximization, and on the other hand, a normativism introduced into sociology mainly by Émile Durkheim, which insists on the anteriority of society in relation to individual agency, thus conceptualizing the latter mainly as norm conformity. The second problem with this theoretical deadlock is that both paradigms convey quite decisive theoretical exclusions, which however are very difficult to maintain: The Rational Choice paradigm denies the genuine dynamics of social processes beyond a notion of accumulated individual actions, and normativism excludes the genuine dynamics of individual motivations from the analytical agenda.

This twin problem, as is suggested in that debate, can be resolved through the concept of the gift. Put briefly, it is argued that the gift constitutes a social relationship which is totally oriented toward neither utilitarianism nor norm conformity, but instead materializes in an array of practices between these two poles. A gift cannot be forced, and thus is necessarily based on voluntariness, yet also follows in its dynamic social conventions. Conversely, the return of the gift cannot be forced either, yet is present as a future potentiality and expectation from the moment the gift is received. In other words, voluntary action, however motivated by utilitarian rationalities, becomes immediately entangled in expectations and expected expectations, yet cannot be reduced to them without the gift losing its character as being voluntarily given. Additionally, the gift is not just reciprocal exchange, as the giver can never be certain if he or she will be given something in return, and what that something might be. Alain Caillé has drawn a connection between the condition of possibility for political agency and the logic of the gift, consisting in the ability of humans to voluntarily enter into obligations - that is, pacts - and to dissolve those very obligations [Caillé 2008: 165-197]. Frank Adloff seconds Paul Ricœurs's characterization of the gift relation as an 'asymmetry of mutuality', the core of which is not the reciprocation of the given value but rather a turn toward the other which materializes already in the initial gift offering, and thus prior to any concluded reciprocity [Adloff 2016: 31-32].

These reconstructions of the logic of the gift envisage a social theory which foregrounds the general multifactoriality of the dynamics of social relationships

1 Perspectives on this debate can be found, for instance, in Caillé [2008], Adloff/Mau [2005], and Adloff [2016]. 
and processes of sociation or interdependence. The very concept of 'gift' condenses these various factors primarily through integrating two, seemingly mutually exclusive, logics: that of the voluntariness (in the Rational Choice paradigm processed as utilitarianism) and that of the normative orientation of social action (in the history of social theory generally associated with the anteriority of society and its means to sanction individuals' deviance from the norm). The fact that in gift exchange the norm to reciprocate cannot be forced onto the receiver is not evidence of that norm's weakness, but rather the precondition for a much greater normative force, namely, that of a norm that foregrounds the act of being opted for voluntarily. In the context of a sociology of European integration, the point here is that sociation, inasmuch it is based on the vehicle of value as that which ought to be wanted but cannot be forced, does not entail the 'cultural doping' (Harold Garfinkel) of norm-obedience, but rather the making of decisions and the bearing of possible consequences. In this sense, values are stabilized in their normative quality as they urge/offer individuals to take the responsibility to opt for them.

This social-theoretical perspective does not preclude the empirical possibility that the logic of gift empirically undergoes transformations toward one or the other pole between which it locates itself. For instance, the logic of gift might undergo shifts that empirically approximate it to the pole of utilitarianism, like in economic trade. It would therefore be misleading to conceptually and rigorously juxtapose the logic of gift and that of economic exchange, as Adloff explains in his critique of Marcel Hénaff [Adloff 2016: 33, 43, referring to Hénaff 2009]. Conversely, the logic of gift might approximate the pole of social normation and coercion, such as in contemporary regimes of tackling relationships between economic debtors and creditors, for instance [Adloff 2016: 34]. The analytical surplus of this social-theoretical reconstruction of the logic of gift as a fundamental mode of understanding sociality thus resides not in its normative affirmation but in the service it can do to render conceptually nuanced reconstructions of empirical practices of exchange, with the logic of gift serving as a conceptual contrasting foil.

The preceding three subsections have outlined a theoretical platform, informed by anthropological and social theory, for understanding exchange as a practice whose logic moves within a broader array of value-producing practices. Exchange is thus neither a form of valuation per se nor exclusively, but rather points to the social potentialities of valuation. The logic of the gift, as reconstructed in recent readings of Mauss, can thus be seen as a paradigmatic way to more generally conceptualize value-creating practices. Value, in turn, is understood as the potentiality of valuation to combine the elements of both social normation and 
individual motivation, and thus to effect sociality. Value can thus be understood as emerging from a deliberate decision to not only adhere to, but embrace, a social norm regulating mutuality. At this point, we will return to the sociology of the European Union and look into town twinning as a field of practices where these dynamics - including some of their recent transformations - can be made empirically visible and related to the EU's integration project.

\section{TOWN TWINNING AS A PRACTICE OF EXCHANGE AND VALUATION}

Town twinning, gaining ground and broadening out in Europe after the end of World War II, has traditionally been viewed as a genuinely civic practice which aims to foster civic exchange and increase mutual understanding among the populations of the European nation-states. Even prior to the signing of the first treaty of economic cooperation (the European Coal and Steel Community (ECSC) in 1951), visits of delegations between British, French, and German cities had already been made and the first formal twinning agreements had been signed [Mirek 1989; Weyreter 2004]. While initially the idea of establishing durable contacts between cities referred first and foremost to the exchange of political office holders and administrative staff, soon the idea was broadened out and a multiplicity of groups from the involved municipalities were included into the exchange: pupils and sports teams, but also 'ordinary' citizens who were encouraged to meet people from the partner cities and to engage in long-lasting relationships. To this end, the town twinning movement became embedded within the grand project of achieving "a citizens' Europe" [Ullrich 1994: 8; Gaspari 2002].

Since the 1950s, town twinning in Europe thus relied on the exchange of delegations and parts of the involved towns' populations for the organization of joint cultural events or programs of political and intercultural education, and on rituals of gift exchange, hospitality, and commensality. Thereby, town twinning went through historical stages of different priorities. While in the 1950s and into the 1960 s the overall focus of town twinning related to the forging of lasting relationships - often referred to as 'friendships' - between individuals and families who typically visited each other once a year or so, in the 1960s the focus began partially shifting to programs of civic education (in particular, of children and adolescents) with the goal to challenge mutual stereotypes about the other nation [see Grunert 1981: 56-77; Farquharson/Holt 1975; Langenohl 2015: 21-24]. In the 1970s, twinning became politicized to a certain degree, as bigger cities were held capable of engaging in an 'alternative foreign policy', especially with 
cities in state socialist countries, following a vision of peaceful coexistence and international cooperation uncorrupted by the logic of the Cold War friction between East and West [Langenohl 2015: 24-29]. The idea that cities might attain a political subjectivity of their own was then revisited after the end of the Soviet Union and state socialism: International inter-city relations were deemed capable of articulating a political avant-garde of what was held to be an emerging postnationalism in international relations [Joenniemi 1998; Wagner 1998].

Town twinning practices vary to some degree with the size of the cities involved. While big cities have created budgets and administrative roles for permanently maintaining the exchange in a way that can be politically overseen, twinning practices in small towns [like those I analyzed in an empirical study carried out in Germany, see Langenohl 2014, 2015, 2017] have to rely more on voluntary engagement that is often carried out within the framework of civic associations such as sports clubs, voluntary firefighter brigades, or twinning committees. Yet what is common to them, and crucial within the context of this article, is that civic participation in twinning does not presuppose specific social or professional roles, as virtually all residents in a given municipality can decide to take part in visits, to host guests, and to co-organize cultural, educational, or social events. The motivation to take part in these activities, apart from 'instrumental' motivations like learning languages or expanding one's international cultural literacy, is often explained by practitioners as an adherence to 'friendship' that manifests itself in reciprocal visits and gifts. The more people that engage in offering hospitality to the guests - for instance, through opening their living spaces or recreational resources (such as access to weekend houses) - the deeper 'friendship' is perceived to be. Twinning practitioners thus tend to see the value of twinning in the voluntary broadening and deepening of sociability and in the exchange of resources that increase the amenability of the visits and materialize hospitality.

What is at stake here however, is more than the insistence on the voluntary basis of twinning exchange: It is instead the difference between a routine exchange of gifts and counter-gifts and the fragility of the expectation that an offer will actually be welcomed and returned. This precarity of the voluntary act can be best seen on occasions when there is an increased likelihood that the voluntary offer might be rejected. Such occasions are often referred to by my interlocutors when they recalled the beginnings of their respective town's twinning relationships, characterizing those beginnings as fraught with uncertainty concerning how the partnership offer will be received by the prospective hosts. For instance, such 
a narrative can be found in an account given about the beginnings of the twinning exchange with a French town in the 1950s: ${ }^{2}$

In October 1959 [one year before the official twinning] the boys and girls of the TTG Tiefwalden Gymnastics Club, to which we belonged with our 1862 Tiefwalden club, travelled under the supervision of our leader, Trude Kowalski, to the French town of Saint-Ambroise. The mayor at the time, Peter Degen, had set up the link and in a clever move had let the young dancers make the first contacts with Saint-Ambroise. And the French newspaper [...] wrote at the time that 1,500 people had gathered. When you think about that, just after, or fairly shortly after the war, [reads out:] 'the folk dancing group presented themselves in a way that drew a lot of attention', as the French newspaper put it at the time.

A related motif can be seen in a conversation with a group of twinning practitioners, among them a former mayor, who referred to the foundation of a twinning relationship with a Polish town in the following way:

I was interrogated in a manner of speaking by the parliament there for over an hour [...] about why we were coming, that is, whether we're coming for revanchist purposes to - because you have to say that the Poles were still afraid at that time. 'The Germans are returning', we're 'taking the country back again'. They were really afraid. And it wasn't that easy at all to dispel this distrust and to show them, yes, we've dealt with that one, we're there as - as friends, as friends of your country. And we want to remove preconceived ideas, and want to have a perfectly normal relationship with you, as with every other country as well. And it wasn't easy to remove those doubts.

A third example comes from a conversation with a person engaged in twinning for 40 years who recalls uncertainty about being welcomed during their first visit to the French town:

The first time we were down there we took a wreath for the Fallen Soldiers' Memorial, and it was to be laid down, and a plan was worked out with the Mayor's office to walk through part of the town center in a procession to the war graves' memorial. And then we suddenly heard the rumor from Court Vieux, a town about 30 kilometers away, that some right-wing extremists would be coming who wanted to cause trouble. And everybody got extremely nervous and we're there with very divided feelings and lined up for the procession and were thinking, let's hope it goes off well, and it did go off well too. You couldn't help but notice that there was a real tension in the air.

Obviously, the interview excerpts presented here formulate historicizing positionalities, formulating viewpoints that are in various respects sensitive to the difficulties Germans travelling to other European countries might expect in the presence of memories of Nazi Germany and the Second World War [see Langenohl 2017]. However, on the structural level, they paint a common picture of a situation

2 In the following interview excerpts, all names of persons and places have been changed for confidentiality. 
in which a 'first' visit is being paid and an invitation to engage in a relationship is extended, yet in a kind of adverse historical constellation and without any guarantee that the offer will be welcomed. It is this uncertainty, bordering on unlikeliness, that places a paramount, almost dramatic, significance on the act of welcoming as it is anticipated, or feared to be withheld, in my interlocutors' narratives. Being 'welcomed' in this context denotes two interrelated, yet paradoxical, things. First, the welcoming gesture, as anticipated, seems to stabilize the motivational structure out of which the offer can emerge. It is, so to speak, the hope that the offer will be welcomed and accepted that motivates the gift. This, I contend, is possible only if the giver can expect his or her addressee to be prepared for the gift - that is, he or she must be able to assume that the norm of hospitality (to accept the gift of the visit) will work even under strained circumstances like the ones referred to by my interlocutors. Yet secondly, the acceptance and welcome of the offer, if achieved, will already exceed what can reasonably be hoped for - all three interlocutors allude to the relative unlikeliness of being welcomed.

Within the conceptual framework of gift-organized sociality developed in the last section, it is my interpretation that the acceptance and welcoming of the offer, precisely because it seemed so unlikely, equates the difference between norm-obedience (accepting the visit politely, enduring it) to embracing a norm. The initial offer - in the cases discussed here, the visit to the future twinning partner or to potential hosts - does respond to an expectation, but not in the sense of the execution of a normative demand, rather in the sense of a hope that the offer might actually be expected and the receiver actually prepared to accept it. It is precisely this hope for the existence of a norm to accept the offer on the side of the receiver which frees the motivational potential triggering the offer. Conversely, to see the offer (the visit) accepted and welcomed leaves a lasting impression precisely because acceptance and welcoming take place against the historical odds, revealing the voluntary embracement of a norm to accept the voluntary offer on the side of the receiver.

From the viewpoint of European integration, the significance of town twinning as a practice revolving around exchange thus resides in a capacity to create occasions on which, through practices of voluntary exchange, norms of transnational sociality can be embraced and actively engaged in. The value of reciprocal hospitality and the friendship emanating from it thus emerges from a decision that exclusively be made in a voluntary spirit: Hospitality, friendship, and welcoming are valued precisely because they are the result of a commitment that may as well have been declined. 
Recently however, judging by my interviews with twinning practitioners in small towns, practices of voluntary exchange have been undergoing change. Literature on inter-town connections and networks states that such connections are increasingly under the influence of political and administrative projects concerning the towns and cities involved. Grosspietsch [2009] argues that town twinning is approximating other inter-city links, like thematic city networks dedicated to increasing the economic potential and competitiveness in global markets or to improving urban infrastructures. In this process, town twinning comes under the tutelage of a mode of Europeanization that is oriented toward governance [Grosspietsch 2009: 1281]. In this tendency, the European Commission (EC) is a major factor. Since 1989, the EC has seen town twinning as a key arena for deepening the legitimacy of the European polity in its citizens, and as a vehicle to boost economic, ecological, and generally urban development [Grosspietsch 2009: 1296]. Additionally, the EU has become the most important funder of town twinning, yet it frees up funding only on the condition that mutual 'projects' aiming at specific improvements in the participating municipalities be planned, conducted, and evaluated [Langenohl 2015: 30-32].

This impacts on the 'intrinsic' value of twinning exchange, pushing it into a more instrumentalist direction. Practitioners report that they are now often busy with planning and drafting grant applications to the EU for twinning-related projects as a means to keep the exchange in operation. Hence, instrumentalist forms of sociality that resemble business meetings (sometimes held not even in the towns themselves but at airports which can be easily reached by all international participants in the applications) rise in importance. Some practitioners deplore this tendency, as for them it relocates the genuine value of town twinning, 'friendship', to the background. The EU perspective of town twinning as vehicle of governed Europeanization, and the rules of project-oriented budget allocation associated with it, creates pressure in inter-town cooperation which may undermine parts of the voluntary basis of the respective commitments, as the twinning constituency is split into a professional and a 'lay' part, depriving twinning-related sociality of its quality as a norm that can be voluntarily engaged with.

\section{CONCLUSION}

This article has suggested an approach to the sociology of the European Union which consists of two steps, namely, a social-theoretical reconstruction of vernacular concepts structuring the debate about European integration (like 'value' and 'exchange'), and the use of those reconstructed conceptual items to 
shed light on the peculiar logics of practice fields of transnationalism within the European Union. This way, 'value' and 'exchange' were displaced as seemingly self-evident political categories and made visible as harboring a potential social theory of European integration on the socio-cultural level within the paradigm of the gift. Then, this conceptualization was used as a heuristic to depict the logics of town twinning as a field of transnational practices that are crucially organized around the valuation of exchange as a process in which transnational sociality can attain an existence as a norm that is not only effective, but can be valued and embraced.

Moreover, the case study highlights a contemporary tendency to reduce the voluntary aspect of valuation to the advantage of imposed, administered, or 'nudged' value prescriptions. What, from a normative perspective interested in the fundamentals of European 'integration', might seem most problematic about this tendency is that it removes the valuation component of voluntarily opting for a norm which is capable of rearticulating, and potentially fostering, its moral foundations. In the case of town twinning, the motivation to voluntarily practice hospitality and engage in joint enjoyment is displaced by an increasingly professional and managerial logic that ties town twinning to instrumentally achieving outcomes deemed to deepen European integration on a socio-cultural and 'governmental' level. For the European Union as a political project - which it maybe still is - this means that it must heed the difference between enacting norms of European integration and creating opportunities in which these norms can be adhered to, embraced, and indeed, welcomed.

\section{BIBLIOGRAPHY}

Adloff Frank, Steffen Mau. 2005. “Giving social ties. Reciprocity in modern society”. European Journal of Sociology 47: 93-123.

Adloff Frank. 2016. Gifts of cooperation. Mauss and pragmatism. London/New York: Routledge.

Bach Maurizio. 2015. Europa ohne Gesellschaft. Politische Soziologie der Europäischen Integration. Wiesbaden: Springer VS.

Beck Ulrich, Gerald Delanty. 2006. Europe from a cosmopolitan perspective. In: Europe and Asia beyond East and West, G. Delanty, (ed.), 11-23. London/New York: Routledge.

Caillé Alain. 2008. Anthropologie der Gabe, trans. by Frank Adloff and Christian Papilloud. Frankfurt a.M./New York: Campus.

Clarke Nick. 2009. 'In what sense 'spaces of neoliberalism'? The new localism, the new politics of scale, and town twinning”. Political Geography 28: 496-507.

Clarke Nick. 2011. "Globalising care? Town twinning in Britain since 1945". Geoforum 42: $115-125$. 
Díez Medrano Juan. 2011. Social class and identity. In: Sociology of the European Union, A. Favell, V. Guiraudon (eds.), 28-49. Basingstoke/New York: Palgrave Macmillan.

Fajans Jane. 1993. Exchanging products - producing exchange. In: Exchanging Products - Producing Exchange, J. Fajans (ed.), 1-13. Sydney: University of Sydney.

Farquharson John E., Stephen C. Holt. 1975. Europe from below: An assessment of Franco-German popular contacts. London: George Allen \& Unwin Ltd.

Favell Adrian. 2008. Eurostars and Eurocities. Free movement and mobility in an integrating Europe. Malden/Oxford/Carlton: Blackwell.

Favell Adrian, Ettore Recchi. 2011. Social mobility and spatial mobility. In: Sociology of the European Union, A. Favell, V. Guiraudon (eds.), 50-75. Basingstoke/New York: Palgrave Macmillan.

Favell Adrian, Virginie Guiraudon. 2011. Sociology of the European Union: An introduction. In: Sociology of the European Union, A. Favell, V. Guiraudon (eds.), 1-24. Basingstoke/New York: Palgrave Macmillan.

Fernandez Juan J., Monika Eigmüller, Stefanie Börner. 2016. "Domestic transnationalism and the formation of pro-European sentiments". European Union Politics 17(3): 457-481.

Gaspari Oscar. 2002. "Cities against states? Dreams and shortcomings of the European municipal movement, 1900-1960”. Contemporary European History 11, 4: 597-621.

Graeber David. 2001. Toward an anthropological theory of value: The false coin of our own dreams. Basingstoke: Palgrave.

Grosspietsch Julia. 2009. "More than food and folk music? Geographical perspectives on European town twinning". Geography Compass 3(3): 1281-1304.

Grunert Thomas. 1981. Langzeitwirkungen von Städtepartnerschaften. Ein Beitrag zur europäischen Integration. Kehl am Rhein/Straßburg: N.P. Engel Verlag.

Hénaff Marcel. 2009. Der Preis der Wahrheit. Gabe, Geld und Philosophie, trans. by Eva Moldenhauer. Frankfurt a.M.: Campus.

Jayne Mark, Phil Hubbard, David Bell. 2011. "Worlding a city: Twinning and urban theory". City 15(1): 25-41.

Joenniemi Pertti. 1998. Cities as international actors: The nexus between networking and security. In: From Town to Town: Local Authorities as Transnational Actors, C. Wellmann (ed.), 29-36. Münster: LIT.

Joenniemi Pertti, Jarosław Jańczak. 2017. "Theorizing town twinning: towards a global perspective". Journal of Borderlands Studies 32(4): 423-428.

Krossa Anne Sophie. 2009. "Conceptualizing European society on non-normative grounds: Logics of sociation, glocalization and conflict”. European Journal of Social Theory 12: 249-264.

Krossa Anne Sophie. 2011. Society. In: Europe in a Global Context, A.S. Krossa (ed.), 91-102. Basingstoke/New York: Palgrave.

Langenohl Andreas. 2014. "Facing one another: Ethics of friendship in town twinning". Przegląd Socjologiczny 63(1): 27-47.

Langenohl Andreas. 2015. Town twinning, transnational connections, and trans-local citizenship practices in Europe. New York/Basingstoke: Palgrave Macmillan

Langenohl Andreas. 2017. "The merits of reciprocity: Small-town twinning in the wake of the Second World War". Journal of Borderlands Studies 32(4): 557-576.

Leitner Helga. 2004. The politics of scale and networks of spatial connectivity: Transnational interurban networks and the rescaling of political governance in Europe. In: Scale and Geographic Inquiry, E. Sheppard (ed.), 236-255. Malden, MA/Oxford: Blackwell. 
Lottermann Annina. 2009. Von bilateralen Initiativen der Völkerverständigung zu multilateralen Foren der praktischen Kooperation - Städtepartnerschaftliche Zusammenarbeit in Europa gestern und heute. In: Entwicklungsfaktor Kultur. Studien zum kulturellen und ökonomischen Potential der europäischen Stadt, G. Quenzel (ed.), 213-236. Bielefeld: transcript.

Lottermann Annina. 2010. Transnationalisierung und Europäisierung. Wie deutsch-polnische und deutsch-türkische Städtepartnerschaften ein transnationales Europa kreieren. In: Transkulturalität, Transnationalität, Transstaatlichkeit, Translokalität. Theoretische und empirische Begriffsbestimmungen, M. Hühn, D. Lerp, K. Petzold, M. Stock (eds.), 115-131. Münster/Hamburg/London: LIT.

Lottermann Annina. 2016. Partnerschaften in eigener Sache. Der gegenwärtige Wandel des Nachkriegsformats Städtepartnerschaften in deutsch-polnischen und deutsch-türkischen Verbindungen des Ruhrgebiets. Eine kulturanthropologische Studie. Inaugural dissertation to the acquisition of the academic degree of a doctor of the philosophy (PhD) in the department of Linguistics and cultural sciences of the Goethe University to Frankfurt am Main.

Malinowski Bronislaw. 1922. Argonauts of the Western Pacific. London/New York: Routledge/ Dutton.

Mau Steffen. 2010. Social transnationalism: Lifeworlds beyond the nation state. London/ New York: Routledge.

Mau Steffen, Jan Mewes. 2012. "Horizontal Europeanisation in contextual perspective: what drives cross-border activities within the European Union?" European Societies 14(1): 7-34.

Mauss Marcel. 1954 [1925]. The gift. Forms and functions of exchange in archaic societies [1925]. New York: W.W. Norton.

Mirek Holger. 1989. Die Entwicklung von Städtepartnerschaften. In: Kommunale "Außenpolitik”. Zur Auslandsarbeit der Gemeinden und zu den innerdeutschen Städtepartnerschaften, P. v. Kodolitsch (ed.), 33-46. Berlin: Deutsches Institut für Urbanistik.

Mol Christof Van, Helga A.G. de Valk, Leo van Wissen. 2015. "Falling in love with (in) Europe: European binational love relationships, European identification and transnational solidarity". European Union Politics 16(4): 469-489.

Munn Nancy. 1992 [1986]. The fame of Gawa: A symbolic study of value transformation in a Massim (Papua New Guinea) Society. Durham/London: Duke University Press.

Strathern Marilyn. 1992. Qualified value: the perspective of gift exchange. In: Barter, exchange and value: An anthropological approach, C. Humphrey, S. Hugh-Jones (eds.), 169-191. Cambridge/New York: Cambridge University Press.

Ullrich Hartmut. 1994. Vorwort. In: Gemeindepartnerschaften im Umbruch Europas, A. Jünemann, E.U. Richter, H. Ullrich (eds.), 7-11. Frankfurt a.M.: Peter Lang.

Villiers de J.C., T.J. de Coning, E.v.d.M. Smit. 2007. "Towards an understanding of the success factors in international twinning and sister-city relationships". South African Journal of Business Management 38(1): 1-10.

Vobruba Georg. 2008. "Die Entwicklung der Europasoziologie aus der Differenz national/europäisch". Berliner Journal für Soziologie 18(1): 32-51.

Vobruba Georg. 2012. The social construction of the European society. In: Theorizing modern society as a dynamic process, H.F. Dahms, L. Hazelrigg (eds.), 263-279. Bingley: Emerald.

Wagner Beate. 1998. Twinnings: A transnational contribution to more international security? In: From town to town: Local authorities as transnational actors, C. Wellmann (ed.), 37-44. Münster: LIT. 
Weiner Annette B. 1992. Inalienable Possessions: The paradox of keeping-while-giving. Berkeley/Los Angeles/Oxford: University of California Press.

Weyreter Martina. 2004. "Germany and the town twinning movement". The Contemporary Review 282: 37-43.

Andreas Langenohl

\section{INTEGRACJA EUROPEJSKA, WARTOŚCIOWANIE I WYMIANA. W STRONE UJĘCIA TRANSNARODOWYCH RELACJI SPOLECZNYCH W UNII EUROPEJSKIEJ W KATEGORIACH TEORII WARTOŚCI}

Streszczenie

Artykuł proponuje konceptualizację pojęcia „wartości” w odniesieniu do problematyki integracji europejskiej. W politycznej retoryce Unii Europejskiej „integracja” to zwykle zarówno poszerzenie zakresu różnych polityk oraz obszarów społecznych, które objęte są rządzeniem ponadnarodowym, jak i pogłębienie regulacji. Natomiast termin „wartość” zwykle stosowany jest w liczbie mnogiej i oznacza określone zasady, często uznawane za nieodłączną część europejskiego dziedzictwa kulturowego i projektu politycznego Unii Europejskiej. W odróżnieniu od tego rodzaju dyskursów ten artykuł proponuje analizę integracji poprzez spojrzenie skierowane ku transnarodowym relacjom społecznym w Unii Europejskiej, a także konceptualizację „wartości” jako kategorii, która nie odnosi się do zasad i przekonań, lecz do wartościowań wbudowanych we wspomniane transnarodowe relacje. Socjologia Unii Europejskiej, mimo znacznego dorobku w postaci licznych studiów nad transnacjonalizmem w Europie, nie rozwinęła póki co określonej koncepcji pojęcia „wymiany”. Przedłożony artykuł stara się wypełnić tę lukę poprzez konceptualizację opracowań antropologicznych, które łączą kwestie społecznego wartościowania z analizą praktyk wymiany. Rezultatem tych poszukiwań jest ujęcie wartościowania społecznego jako zjawiska wyłaniającego się z wymiany wywodzącej się z logiki „daru”. Taka konceptualizacja jest następnie zastosowana do analizy jednej z doniosłych, powszechnych i mających długą tradycję praktyk wymiany w Unii Europejskiej - partnerstwa miast. Odnosząc się do wyników jakościowego projektu badawczego przeprowadzonego przez autora, artykuł wskazuje na to, jak określone interpretacje wymiany partnerskiej skutkują wartościowaniem transnarodowych relacji europejskich, a jakie czynniki takiemu wartościowaniu przypuszczalnie przeczą. Artykuł zamykają konkluzje dotyczące ogólnych implikacji zaproponowanego podejścia.

Słowa kluczowe: Unia Europejska, integracja europejska, wartość, wymiana, relacje społeczne, uspołecznienie, partnerstwo miast 